\title{
Study of 140 Thyroidectomy Patients to Find Out the Incidence of Thyroid Malignancy in Thyroid Swelling
}

\section{Matin MA1, Raquilb A $^{2}$, Saiful Islam $\mathbf{M}^{3}$, Shaif Uddin $\mathrm{AKM}^{3}$, Islam N4, Ahsan Z5 , Azad AK ${ }^{6}$, Mamun Murshed KM7, Sobhan AKMA7, Md.} Shahjahan Kabir ${ }^{7}$, Md. Abdullah Al Harun ${ }^{8}$ and Md. Abdur Razzak ${ }^{8}$

${ }^{1}$ Professor and Head of ENT and HNS, Shaheed Suhrawardy Medical College and Hospital, Bangladesh

${ }^{2}$ Associate Professor of ENT, Otolaryngology Popular Medical College, Bangladesh

${ }^{3}$ Asstt. Professor of ENT, Shaheed Suhrawardy Medical College and Hospital, Bangladesh

${ }^{4}$ Senior Consultant of ENT, Mohammad Ali Hospital, Bangladesh

${ }^{5}$ Associate Professor of ENT, TMSS Medical College, Bangladesh

${ }^{6}$ Senior Consultant of Paediatrics, Khulna Medical College, Bangladesh

${ }^{7}$ Associate Professor of ENT Shaheed Suhrawardy Medical College and Hospital, Bangladesh

${ }^{8}$ Resident Surgeon of ENT, Shaheed Suhrawardy Medical College and Hospital, Bangladesh

*Corresponding author: MA Matin, Professor and Head of the Department of ENT and Head Neck Surgery, Shaheed Suhrawardy Medical College Hospital, Dhaka 1207, Bangladesh, Email: matinfrcs@yahoo.com

\section{Abstract}

Objective: To compare FNAC with histopathology reports and to find out the true incidence of thyroid malignancy in thyroidectomy patients presenting with thyroid swelling.

Materials \& Methods: This is a prospective study of 140 thyroid swelling patients underwent thyroid surgery done at Matin Specialized Hospital, Bogura from January 2016 to July 2019. FNAC and histopathology reports were studied to find out the incidence of benign and thyroid malignancy among the thyroid swelling.

Results: The age of the patients ranged from 6 to 70 years. The mean age was 38.6 years. There were 110 female and 30 male patients with female male ratio 3.6:1. Diagnostic categorization of 140 thyroid swelling underwent surgery, FNAC $s$ based on Bathesda classification showed that 110 (79.28\%) cases were cytologically benign, 25 (17.85\%) cases were malignant category. Out of 140 cases histopathology showed 94 cases (67.14\%) are benign and 46(32.85\%) are malignant thyroid swelling. Among the benign lesions $90.42 \%$ is colloid goitre and among the malignant lesions $91.3 \%$ are papillary thyroid carcinoma. 


\section{Otolaryngology Open Access Journal}

Conclusion: Although FNAC is an essential diagnostic test to rule out thyroid malignancy but histopathologial examination is the only way to give true incidence of thyroid malignancy among the thyroid swelling and it is observed that there is high incidence of thyroid malignancy (32.85\%) among the thyroid swelling patient.

Keywords: FNAC; Histopathology; Thyroid malignancy

\section{Introduction}

Bangladesh especially North Bengal area is an endemic zone for iodine deficiency goitre and most of the patient of this study are from this endemic area. They present as visible neck swelling which moves on deglutition. Any patient presented with thyroid swelling are routinely investigated for ultra-sonogram of the thyroid gland, serum TSH and FNAC. Final diagnosis requires morphological examination for which histopathological examination becomes mandatory test [1]. In 1870 Rugu and his associate Joham Vent have first advocated surgical biopsy as an essential tool [2]. The diagnostic method of FNAC was first published in 1883 by Leyden. But the diagnosis of thyroid swellings using aspiration cytology was first reported by Martin and Ellis in 1930. FNAC, however has limitation related to specimen adequacy, sampling techniques, skill of performing the procedure, interpretation of the aspirate, overlapping cytological features between benign and malignant follicular neoplasm and also in the detection of some papillary carcinoma associated with other pathology like multinodular goitre, cystic changes [3-5]. Mundasad, et al. had done a comparative study between FNAC and histopathology and founded that FNAC had a sensitivity $(52.6 \%)$, specificity $(86.6 \%)$ and accuracy $(79.1 \%)$ for thyroid malignancy [6].

\section{Aims and Objectives}

This study was carried out to see the true incidence of benign and malignant thyroid lesions among the thyroid swellings after histopathological examinations following thyroidectomy.

\section{Materials and Methods}

This cross sectional study was done among patients undergoing thyroidectomy between January 2016 to July 2019 at Matin Specialized Hospital, Bogura, Bangladesh. The patients were selected consequently as and when they presented during the study period considering inclusion and exclusion criterias. The selected patients were examined clinically and routine ultra sonography,
TSH, FNAC, routine haematological investigations, Chest X-ray ECG, CT scan if indicated were done. All patients FNACs were done by a single senior cytologist. All surgeries were done by the single principal Author and all thyroidectomies specimens were examined by one senior histopathologist.

\section{Statistical Analysis}

The data collected was analysed using SPSS version 20 and depicted using descriptive statistics.

\section{Inclusion Criteria}

Patients with thyroid swelling with normal thyroid hormone profile undergoing thyroidectomy.

\section{Exclusion Criteria}

Patients of thyroid swelling with hyper or hypo thyroid function, patients with co-morbidities, unfit for surgery, patients who refused surgery and inoperable thyroid malignancy were excluded from the study.

\section{Results}

The age of the patients ranged from 6 to 70 years with a mean age 38.66 years (Table 1). The thyroid lesions were more common in females than male in a ratio of 3.66:1. Tables $2 \& 3$ shows FNAC findings of 140 cases where 115 are benign and 25 cases are malignant lesion with benign malignant ratio is 4.6:1. Among the benign lesions the most common lesion is multi nodular or colloid goiter. Table 4 shows out of 25 malignant cases of FNAC finding, $92 \%$ is papillary carcinoma. Histopathological examinations of all 140 thyroidectomy specimens showed 85 cases $(60.71 \%)$ are colloid goiter and 40 cases $(28.57 \%)$ are papillary carcinoma (Tables 5 $\& 6)$ shows incidence of benign and malignant lesions among 140 specimens. There are 94 (67.14\%) benign lesions and 46 (32.85\%) malignant lesions, so approximately benign and malignant ratio is about 2:1 which is very worrying. Finally among the thyroid cancer about $91 \%$ is papillary carcinoma Table 7 . 


\section{Otolaryngology Open Access Journal}

\begin{tabular}{|c|c|c|}
\hline Age in years & No. of patients & Percentage (\%) \\
\hline Jun-20 & 5 & 3.57 \\
\hline $21-30$ & 23 & 16.42 \\
\hline $31-40$ & 54 & 38.57 \\
\hline$>40$ & 58 & 41.42 \\
\hline Mean age 37.66 & & \\
\hline
\end{tabular}

Table 1: Age distribution of thyroidectomy patients (N140).

\begin{tabular}{|c|c|c|}
\hline Sex & No. of patients & Percentage (\%) \\
\hline Female & 110 & 78.57 \\
\hline Male & 30 & $21 . .42$ \\
\hline \multicolumn{2}{|c|}{ Female: Male $=3.66: 1$} & \\
\hline
\end{tabular}

Table 2: Sex distribution (N-140).

\begin{tabular}{|c|c|c|}
\hline Diagnosis & $\begin{array}{c}\text { No. of } \\
\text { patients }\end{array}$ & $\begin{array}{c}\text { Percentage } \\
\text { (\%) }\end{array}$ \\
\hline Nodular or colloid goiter & 110 & 79.28 \\
\hline Papillary thyroid carcinoma & 23 & 15.71 \\
\hline Follicular lesion & 4 & 2.85 \\
\hline Lymphocytic thyroiditis & 1 & 0.71 \\
\hline Non Hodhkin,s lymphoma & 1 & 0.71 \\
\hline Medullary carcinoma thyroid & 1 & 0.71 \\
\hline
\end{tabular}

Table 3: FNAC of thyroid swelling $(n=140)$.

\begin{tabular}{|c|c|c|}
\hline Diagnosis & $\begin{array}{c}\text { No. of } \\
\text { patients }\end{array}$ & $\begin{array}{c}\text { Percentage } \\
\text { (\%) }\end{array}$ \\
\hline $\begin{array}{c}\text { Papillary carcinoma of } \\
\text { thyroid }\end{array}$ & 23 & 92 \\
\hline Follicular carcinoma & 0 & 0 \\
\hline Medullary carcinoma & 1 & 4 \\
\hline Non-Hodgkin's lymphoma & 1 & 4 \\
\hline
\end{tabular}

Table 4: FNAC diagnosis of thyroid malignancy (n-25).

\begin{tabular}{|c|c|c|}
\hline Diagnosis & No. of patients & $\begin{array}{c}\text { Percentage } \\
\text { (5) }\end{array}$ \\
\hline Colloid/MNG & 85 & 60.71 \\
\hline Lymphocytic thyroiditis & 7 & 5 \\
\hline Follicular adenoma & 2 & 1.42 \\
\hline Papillary carcinoma & 40 & 28.57 \\
\hline Hurthle cell adenoma & 2 & 1.42 \\
\hline Follicular carcinoma & 2 & 1.42 \\
\hline Medullary carcinoma & 1 & 0.71 \\
\hline Non-Hodgkin's lymphoma & 1 & 0.71 \\
\hline
\end{tabular}

Table 5: Histopathological diagnosis of thyroid swelling (N-140).

\begin{tabular}{|c|c|c|}
\hline Diagnosis & No. of patients & Percentage (\%) \\
\hline Benign lesions & 94 & 67.14 \\
\hline Malignant & 46 & 32.85 \\
\hline
\end{tabular}

Table 6: Incidence of benign and malignant lesions based on histopathology (n-140).

\begin{tabular}{|c|c|c|}
\hline Diagnosis & $\begin{array}{c}\text { No. of } \\
\text { patients }\end{array}$ & $\begin{array}{c}\text { Percentage } \\
\text { (\%) }\end{array}$ \\
\hline $\begin{array}{c}\text { Papillary carcinoma (including } \\
\text { Hurthle cell adenoma) }\end{array}$ & 42 & 91.3 \\
\hline Follicular carcinoma & 2 & 4.34 \\
\hline Medullary carcinoma & 1 & 2.17 \\
\hline Non-Hodgkin, s lymphoma & 1 & 2.17 \\
\hline
\end{tabular}

Table 7: Incidence of thyroid cancer (n-46).

\section{Discussion}

The incidence of thyroid cancer has rapidly increased in the United States (US) and other developed countries over the past 30 years [7]. Although some researchers believe this is a true increase in thyroid cancer, [8] but this increase is due to better diagnostic testing such as ultrasonography and fine-needle aspiration biopsy, resulting in the detection of disease that is unlikely to cause symptoms or death of the patient [9].

Other countries have seen similar increases in thyroid cancer. From 1993 to 2011, South Korea witnessed a 15fold increase in thyroid cancer with nearly the entire increase attributed to papillary cancers [10]. Davies and Welch also showed, using the SEER program and data, that the rates of follicular, medullary and anaplastic thyroid cancers show no significant change from 1973 to 2002 [11]. Our study also found similar result of increasing incidence of thyroid cancer and most of which are papillary carcinoma. The most important part of our study is limitation of FNAC which includes false negative result and false positive results. Sikder had done accuracy of fine needle aspiration cytology and had found that accuracy was $90 \%$ and sensitivity was $68.75 \%$ [12]. Bloch had done a comparison study between FNAC and histopathology and had found accuracy of FNAC was 91.6\% [13]. In our study false positive was 7 and false negative was 23 out of 140 thyroidectomy patients and overall sensitivity were 41\%, specificity 93\%, PPV $69.56 \%$ and NPV $80.17 \%$. 


\section{Otolaryngology Open Access Journal}

\section{Conclusion}

As the incidence of thyroid cancer is increased over the last decade it is also increased in Bangladesh. Our study observed $32.85 \%$ cases are thyroid cancer among the thyroid swelling underwent thyroid surgery. Ultrasonography and FNAC are both essential diagnostic tool for thyroid swelling but final diagnosis to rule out thyroid cancer is surgical excision and biopsy. In our study benign to malignant ratio is about $2: 1$ so FNAC proven benign lesions should not left untreated.

\section{References}

1. Gupta M, Gupta S, Gupta VB (2010) Correlation of Fine Needle Aspiration Cytology with Histopathology in the Diagnosis of Solitary Thyroid Nodule. J Thyroid Res 2010: 379051.

2. Rugu C (1970) Needle Aspiration Biopsy. Am J Pediatr 62: 565-568.

3. Das D, Sarma MC, Sharma A, Datta TK, Lahiri SK (2012) A Comparative study between fine needle aspiration cytology and histopathological examination in the diagnosis of neoplastic and nonneoplastic lesions of the thyroid gland. Indian J Prev Soc Med 43(1): 72-75.

4. Orell SR, Vielh P (2012) The techniques of FNA cytology. In: Orell SR, (Eds.), Fine needle aspiration cytology. $5^{\text {th }}$ (Edn.), Elsevier, pp: 10.

5. Kumar A, Bhadouriya SK, Narain P, Jitendra PSC, Bhartendu Bi, et al. (2017) Comparative study of FNAC and histopathology of thyroid swellings, diagnostic accuracy and role in its management.
International Journal of Otorhinolaryngology and head and Neck Surgery 3(4): 885-892.

6. Mundasad B, Mcallidter I, Carson J (2006) Accuracy of fine needle aspiration cytology in diagnosis of thyroid swelling. Intern J Endocrinol 2(2): 23-25.

7. Vaccarella S, Franceschi S, Bray F, Wild CP, Plummer $\mathrm{M}$, et al. (2016) Worldwide thyroid-cancer epidemic? The increasing impact of over diagnosis. N Engl J Med 375(7): 614-617.

8. How J, Tabah R (2007) Explaining the increasing incidence of differentiated thyroid cancer. CMAJ 177(11): 1383-1384.

9. Kent WD, Hall SF, Isotalo PA, Houlden RL, George RL, et al. (2007) Increased incidence of differentiated thyroid carcinoma and detection of subclinical disease. CMAJ 177(11): 1357-1361.

10. Ahn HS, Kim HJ, Welch HG (2014) Korea's thyroidcancer "epidemic"-Screening and overdiagnosis. New Engl J Med 371: 1765-1767.

11. Davies L, Welch HG (2006) Increasing incidence of thyroid cancer in the United States, 1973-2002. JAMA 295(18): 2164-2167.

12. Sikder MAH, Rahman AZMM, Khair MA (2012) Accuracy of fine needle aspiration cytology in the diagnosis of thyroid swellings. J Dhaka National Med Coll Hos 18(02): 47-51.

13. Bloch M (1997) Fine needle aspiration biopsy of head and neck masses. Otolaryngol Head Neck Surg 89: 6268. 